\title{
LÁTHATATLAN TRANSZFEREK: KI ADJA ÉS KI KAPJA A HÁZTARTÁSI MUNKÁT?
}

\section{Gál Róbert Iván - Szabó Endre - Vargha Lili}

\section{ÖSSZEFOGLALÓ}

A 2009/2010-es időmérleg adatai alapján megvizsgáljuk a háztartásban végzett nem fizetett munka, illetve az e munka révén előállított javak és szolgáltatások fogyasztásának koreloszlásait nemek szerint. Kis leegyszerüsítéssel elvégezzük a háztartásgazdaságot leíró háztartási szatellitszámla elsődleges demográfiai elemzését. Eredményeink a férfiak és nők közötti munkamegosztás jól dokumentált különbségeit pontosítják. A női korprofilra sokkal erőteljesebben jellemző a kétcsúcspontú eloszlás. A nemek közötti különbség a gyermeknevelési életkorokban a legnagyobb, de minden 10 évesnél idősebb korcsoportban jelen van. Mindezt figyelembe véve, a háztartáson belüli időtranszferek igazi nyertesei nem a nemek, hanem a korcsoportok közötti újraelosztásban keresendők. A 30 és 53 év közötti férfiak nettó nyújtói és nem kedvezményezettjei az időtranszfereknek. Egy átlagos 54 év feletti férfi 1,3 havi keresetnek megfelelö értékü időtranszfert kap - egy átlagos gyermek azonban 0 és 17 év között 5,6 havi keresetnyit. A háztartásgazdaság nem csak nemek között, hanem életkorok között mozgat transzfereket.

Tárgyszavak: időmérleg; nemzeti időtranszfer számla; nem fizetett háztartási munka

Gál Róbert Iván, KSH Népességtudományi Kutatóintézet és Budapesti Corvinus Egyetem, E-mail:gal@demografia.hu

Szabó Endre, MTA KRTK Közgazdaság-tudományi Kutatóintézet

E-mail: szabo.endre@krtk.mta.hu

Vargha Lili, KSH Népességtudományi Kutatóintézet, E-mail: vargha@demografia.hu 


\section{BEVEZETÉS: ÉLETPÁLYA-FINANSZÍROZÁS TRANSZFE- REK RÉVÉN}

Az életpálya deficittel kezdődik és végződik. Gyermek- és időskorban többet fogyasztunk, mint amennyit megtermelünk. Ezt ellentételezi az aktív kori többlet. A deficites életszakaszok finanszírozása során kihasználjuk azt a tényt, hogy minden pillanatban élnek aktív korúak, akik erőforrásaik egy részét átadják az aktuálisan inaktív életkorban járóknak. Az életpályát mindig és mindenhol különböző életkorú generációk közötti erőforrás-átcsoportosítás révén finanszírozzák. Ennek a sokcsatornás intergenerációs erőforrás-átcsoportosítási rendszernek része az állam, a háztartások és a vállalati szektor is. Az adófizetők jellemzően aktív korúak, míg a közkiadások kedvezményezettjei inkább inaktív életszakaszukban vannak. A gyermekes háztartások bevételeit a szülők teremtik elő, de ebből gyermekeik is részesülnek. A fiatal aktív korú családalapítók egzisztenciateremtés céljából felvett hitelét többségében a gyermekeiket már felnevelt, nyugdíjra készülő idősebb aktív korú megtakarítók finanszírozzák. Mindez erőteljes demográfiai színezetet ad a jóléti rendszernek, a pénz- és biztosítási piacoknak, valamint a háztartás-gazdaságnak.

Az alábbi tanulmányban a generációk közötti erőforrásáramlási rendszer speciális fejezetével, a háztartási munka révén előállított javakból és szolgáltatásokból származó intergenerációs transzferekkel foglalkozunk. E transzfereket a szakirodalom időtranszfereknek nevezi, mivel a tranzakciók nem pénzben zajlanak. Ugyanakkor, a háztartási szatellitszámla² eszköztárának felhasználása révén az intergenerációs transzferek eme szektora is kifejezhető pénzben, és így beilleszthető az elszámolások általános rendszerébe.

Az időtranszferek kiszámítása a háztartási szatellitszámla fontos felhasználási területe. Az időtranszferek koreloszlása a nyugati társadalmakban erősen aszimmetrikus, méghozzá épp ellentétes irányban, mint az állami részvétellel közvetített közösségi transzferek (pl. a nyugdíjrendszer vagy az egészségügy). Gál, Szabó és Vargha (2015) kimutatta, hogy 2000-ben

\footnotetext{
${ }^{1}$ Köszönettel tartozunk a KSH Nemzeti számlák főosztályának és az Életminőség-statisztikai főosztálynak az együttmüködésért. Sok segítséget kaptunk Szép Katalintól és egy névtelen lektortól. Ők természetesen nem felelősek a tanulmány megállapításaiért. A tanulmány elkészültét az Országos Tudományos Kutatási Alapprogramok támogatta (K109885). Egyes részek megírása során támaszkodtunk korábbi írásainkra, így a Gál és Vargha (2015) tanulmányra.

${ }^{2}$ A nemzeti számlák rendszere lefedi a formális és informális piacgazdaságot, valamint a nem piaci termelés egy részét (a termékeket előállító önkéntes munkát, a házilagos építkezést és a saját fogyasztásra szánt élelmiszer termelését). A háztartások által előállított egyéb termékek és szolgáltatások nem részei a számlarendszernek; azokat (továbbá az önkéntes munka szolgáltatásokban megtestesülő elemeit) a háztartási szatellitszámla tartalmazza.
} 
Magyarországon a közösségi transzferek egy idősre eső értéke több mint kétszerese volt az egy gyermekre eső értéknek. Ha viszont a számításba bevontuk a háztartáson belül gazdát cserélő, vásárolt javakat és szolgáltatásokat (az ún. magántranszfereket), akkor a két érték kiegyenlítődött. Ha pedig még egy lépéssel tovább menve az időtranszfert is figyelembe vettük, kiderült, hogy egy gyermek átlagosan mintegy másfélszer annyi transzfert kapott, mint egy idős. Gál, Vanhuysse és Vargha (2018) megismételte e számításokat az Európai Unió népességének 70\%-át reprezentáló 10 tagállamra, a 2000-es évek elejére. Nagyon hasonló eredményeket kaptak azzal az eltéréssel, hogy a gyermek/idős arány már a magántranszferek bevonása során átfordult, nem pusztán kiegyenlítődött.

Megfigyeléseink a „láthatatlan” transzferekről arra utalnak, hogy az „idősuralomra” vonatkozó politikai állásfoglalásokat és politológiai fejtegetéseket felül kell vizsgálni. Minden olyan okfejtésnek, amely az idősek növekvő számarányából, nagyobb szavazási hajlandóságából, abból, hogy kevés választási témára koncentrálnak vagy más megfigyelésekből vezeti le a növekvő egészségügyi és nyugdíjkiadásokat, számolnia kell azzal, hogy egy gyermeknek többet juttat a társadalom, mint egy idősnek. Sőt, amennyiben igaznak bizonyul az a feltevés, hogy a hagyományos, magas termékenységü társadalmakban az egy gyermekre eső ráfordítások csekélyek voltak, úgy az idősek részletesen dokumentált növekvő részesedése együtt kellett, hogy járjon a gyermekek részesedésének növekedésével. Az idősek nem kizárólagos nyertesei a folyamatnak, csak annak tűnnek, ha az elemzésből kihagyjuk a családtagok közötti intergenerációs transzfereket.

További következtetés, hogy mivel a láthatatlan transzferek a háztartáson belül, rokonok között, elsősorban és főként a szülőktől a gyermekek felé áramlanak, figyelmen kívül hagyásuk elsősorban a gyermeket nevelők elszámolásait torzítja. Éppúgy, ahogy a háztartást és azon belül a nem fizetett háztartási munkát figyelmen kívül hagyó számítások alulbecslik a gyermekeknek adott erőforrások valódi mértékét, a gyermeket nevelők által adott erőforrások is erősen alulbecsültek a jelenleg rendelkezésünkre álló statisztikai rendszerben. A számításból kihagyott tételek kétszer is hiányoznak, először a címzetteknél, nevezetesen a gyermekeknél, másodszor pedig a feladóknál, vagyis a gyermeket nevelőknél. 
A 2. fejezetben a 2010-es magyar időmérleg-felvétel alapján kiszámoljuk a háztartási munka értékét koréves bontásban. Majd a nemzeti transzferszámlák ${ }^{3}$ módszertanát követve megadjuk az e munka révén elóállított javak és szolgáltatások fogyasztásának korprofilját, és a kettő különbözeteként eljutunk a nettó időtranszferekhez. Bemutatjuk, hogy a háztartási javak és szolgáltatások elsődleges haszonélvezői a gyermekek.

A 3. fejezetben a számításokat nemi bontásban is megismételjük. A háztartási munka jól dokumentáltan erőteljes nemi munkamegosztást mutat: a nők lényegesen több munkát végeznek a háztartásban, mint a férfiak. Következésképp az említett torzításnak erős nemi komponense van, a nők számláiból lényegesen több hiányzik, ha a háztartásban végzett munkát nem vesszük figyelembe. Bemutatjuk, hogy e megfigyelés nem pusztán az aggregátumok szintjén, hanem korszerkezetét tekintve is releváns.

\section{IDÖTRANSZFEREK 2010-BEN: A HÁZTARTÁSI MUNKA KORSZERKEZETE}

Az alábbiakban közölt számítások a magyar Nemzeti Transzferszámlák projekt része, amely saját, nemzetközileg elfogadott módszertani megegyezéseket követ.

A nemzeti transzferszámlák (National Transfer Accounts, NTA) rendszere új fejezetet nyitott a nemzeti számlák fejlődésében. Először is bevezette az életkort mint tényezőt a korsemleges nemzeti számlák körébe. A nemzeti számlák jövedelmi számlájának standard formájában a jövedelmek intézmények, például a háztartások, a vállalatok és a kormány között áramlanak. A nemzeti transzferszámlák azt mutatják, hogy e komplex rendszer fő tételei jellemző korprofillal rendelkeznek. A munkajövedelem és a munkát terhelő adók értéke gyermekkorban és idős korban minimális vagy nulla. Ezzel szemben az egyéni és közösségi fogyasztási kiadások, valamint a fogyasztásra rakódó adók egyenletesebben oszlanak el a különböző életkorúak között. A közösségi transzfereket többnyire az aktív korú népesség finanszírozza, fogyasztásuk pedig vagy egyenletes (például a honvédelem és más tiszta közjavak), vagy inkább a gyermekeknél és az időseknél jelentkezik (például az

\footnotetext{
${ }^{3}$ A nemzeti transzferszámlák alapjait Lee (1994a, 1994b) rakta le. A módszer részleteit tartalmazó kézikönyvet az ENSZ Népesedési Igazgatósága adta ki (UN 2013). Részletes bevezetés, ezen belül a módszer elméleti alapjai, összehasonlító eredmények és országtanulmányok széles köre található a Lee és Mason (2011a) kötetben.
} 
oktatás, a nyugdíjak stb.). Az NTA-módszertan másik újítása, hogy új szinttel egészítette ki a nemzeti számlákat. A nemzeti számlák a jövedelmek, így például a munkajövedelem és a vagyoni eredetű bevételek elsődleges allokációját, valamint az adók, illetve a készpénzes és természetbeni juttatások/ támogatások formájában történő másodlagos újraelosztását írja le. Ugyanakkor az adózott jövedelmek háztartáson belüli (például a szülők gyermekeik fogyasztását finanszírozzák) vagy a háztartások közötti (például a nyugdíjas szülők támogatják tőlük külön élő, felnőtt gyermekeiket) harmadlagos elosztása nem jelenik meg a nemzeti számlákban. E tekintetben az NTA a háztartáson belüli és háztartások közötti kapcsolatokkal egészítette ki a nemzeti számlák rendszerét.

Az NTA azonban nem lép túl a nemzeti számlák aggregátumainak - így például a GDP vagy nettó nemzeti jövedelem - határain. A nem fizetett háztartási munka előállítására és fogyasztására is csak olyan szinten terjed ki, amit a jelenlegi statisztikai standardok is figyelembe vesznek a nemzeti jövedelem számításában. Tanulmányunkban kiterjesztjük az eljárást a nemzeti számlák háztartási szatellitszámlájára. ${ }^{4}$ Ezt Donehower (2011) életkorral bővített háztartási szatellitszámlának vagy nemzeti időtranszfer számlának (National Time Transfer Account, NTTA) nevezi. ${ }^{5}$

\section{MÓDSZERTANI MEGJEGYZÉSEK}

Az alábbi elemzés a 2009/2010-es KSH időmérleg-vizsgálaton alapul. A minta a 10-84 év közötti, magán (azaz nem intézményi) háztartásban élő népességet reprezentálja. Az adatgyűjtés a többlépcsős rétegzett mintavételi eljárás során kiválasztott személyek időnaplói alapján történt. A naplózási időpontok reprezentálják a négy évszakot és a hét napjait.

\footnotetext{
${ }^{4}$ A háztartási szatellitszámla az időmérleg-vizsgálatokon nyugszik. Az időmérleg az emberek idő-felhasználását méri fel. Az időráfordítások közül háztartási munkának számít minden olyan tevékenység, melyet valaki más is el tudna végezni a megkérdezett helyett, vagyis amit elvileg fizetett munkával is lehetne helyettesíteni. Az elvégzett háztartási munkát piaci keresetekkel forintosítva megadható a háztartásban végzett nem fizetett munka összértéke. A háztartási szatellitszámla készítésével kapcsolatban az Eurostat (European Communities, 2003) fogalmazott meg módszertani ajánlásokat. Magyarországon az első háztartási szatellitszámla, mely az 1999/2000-es időmérleg alapján készült, a Sik és Szép (2003) szerkesztette kötetben jelent meg - ez volt egyébként a világon az egyik legelső háztartási szatellitszámla. A 2009/2010es időmérlegből számolt háztartási szatellitszámla Szép és Szőkéné (2017) szerkesztésében jelent meg. Ez utóbbi kötet tartalmazza tanulmányunk korábbi változatát.

${ }^{5}$ Az NTTA módszertani ajánlásai Donehower-tól (2011) valók. Európai összehasonlító számításokat közöl Vargha, Gál és Crosby-Nagy (2017).
} 
A 2010-es KSH időmérleg 548 tevékenységet különböztet meg. A tanulmány céljával összhangban a fizetett munkára fordított időt figyelmen kívül hagytuk. A fennmaradó időt a harmadik személy elv alapján háztartási munkára és rekreációs/szabadidős tevékenységekre (a két utóbbit a továbbiakban szabadidős tevékenységnek nevezzük) osztottuk fel. Ennek megfelelően a munka olyan tevékenységet jelent, amelyet másvalaki, egy harmadik személy is elvégezhet a válaszadó helyett (például a házimunka különböző típusait és a gondozással összefüggő tevékenységeket), míg a szabadidős tevékenység nem ruházható át (pl. a sport, az alvás vagy az éttermi étkezés). Elemzésünkhöz 190 tevékenységet választottunk ki. A háztartási munka és a szabadidő közötti különbség nem jelzi, hogy mekkora boldogságot vagy örömöt okoznak. A két típus különválasztásában lényegtelen, hogy az egyén ténylegesen élvezte-e a tevékenységet. A piaci munkához hasonló módon az emberek bizonyos háztartási munkákat szeretnek, másokat nem.

A kérdőiv párhuzamos tevékenységek végzését is lehetővé teszi, mint amikor mosogatás közben segitünk gyermekünknek megírni a házi feladatot. Ha ezek egyike nem fizetett háztartási munka, míg a másik fizetett munka vagy szabadidős tevékenység, és mint ilyen a kutatás tárgyán kívül esik, akkor csak a nem fizetett háztartási munkát vesszük számításba. Ha mindkettő szerepel a 190 tevékenység kiválasztott csoportjában, mindkettőt 0,5-es értékkel súlyozzuk. Ezáltal lehetővé tesszük a párhuzamos tevékenységeket, ám mégis 1440 percre korlátozzuk a napot.

A nemzeti transzferszámlák a nemzeti számlákon alapulnak, amelyek a nem fizetett háztartási munka bizonyos részeit is magukban foglalják, mint például a saját fogyasztásra termelt étel és a saját ház építése. E tevékenységekkel az alábbiakban nem számolunk.

A szakirodalom különbséget tesz a nem fizetett háztartási munka értékelésének output és input módszere között. Azelőbbia tevékenység értékét annak a terméknek az értékéből származtatja, amely a szóban forgó tevékenység során létrejön (például a vacsora). Ez a megközelítés lehetővé teszi, hogy a termelékenységi különbségeket és a méretgazdaságosságot is számításba vegyük, ami az input módszerhez képest előnyt jelent. Sajnos az időmérleg-vizsgálatok jellemzően nem tartalmaznak kellő információt a háztartási termelés kibocsátására vonatkozóan. Más termelési eszközökkel, például a beszámított lakbérrel és a tartós fogyasztási cikkek értékével kapcsolatos adatok szintén erősen korlátozottak. Így az NTTA módszertani standarddal és a házimunka értékéről készitett szinte valamennyi tanulmánnyal összhangban mi is az input megközelítést fogjuk alkalmazni. Csupán az adott tevékenységre fordított időt fogjuk mérni. 
A háztartási munka árazása még az egyszerübb, input megközelítéssel sem egyértelmű feladat. Miként a névből is kiderül, e munkáért senki nem fizet: nincs piaci mechanizmus, ami értéket rendelne hozzá. Az egyes háztartási tevékenységekhez hasonló piaci tevékenységek árainak alkalmazása két problémát vet fel. Először is nem nyilvánvaló, hogy kinek a bérét kellene figyelembe venni: a háztartási munkát végző személyét (feláldozott haszon megközelítés), vagy azét, akinek a munkáját végzik (szakember-bér megközelítés). Az első esetben a felmérés válaszadójának, például egy informatikusnak a bérét vesszük alapul, még akkor is, ha netán éppen mosogat. A második esetben olyasvalakinek a szokásos piaci béréből indulunk ki, aki főállásában mosogat. Tekintve, hogy sok háztartási munkához csupán alapvető vagy semmilyen szakértelem nem szükséges, a haszon-áldozat megközelítés nagyobb értéket társít a háztartási munkához, különösen a férfiak által végzett feladatokhoz, mint a szakember-bér módszer. Az NTTA módszertani ajánlás az utóbbi, a szakember-bér megközelítést alkalmazza.

A bérek a Nemzeti Foglalkoztatási Szolgálat bértarifa-felméréséből származnak. A bértarifa bruttó béreket tartalmaz. ${ }^{6}$

A piaci béreken alapuló értékelési módszer felveti a szelekciós torzítás problémáját. A szakember jellemzően termelékenyebb a háztartási munkát végző átlagembernél, ezért a nem fizetett munka értékét a piaci keresetek átvétele felülértékeli. E torzítás mérséklése érdekében a korábbi NTTA-módszertan minőségkorrekciós tényezőket alkalmazott: 1-es szorzót rendelt a gondozási tevékenységekhez és néhány, szakértelmet nem igénylő feladathoz, 0,75-öt pedig a többihez (lásd Gál, Szabó és Vargha 2015). A legújabb módszertani ajánlás szakít a minőségkorrekcióval, így az alábbiakban nem alkalmazzuk.

A munka termelékenysége függ az életkortól: egy 40 éves ember általában gyorsabban el tud végezni egy feladatot, mint egy 80 éves. Az output-árazás ugyanazt az értéket rendeli hozzá ugyanahhoz a vacsorához, függetlenül attól, hogy az elkészítése mennyi időt vett igénybe. Ezzel szemben az input-árazás a kevésbé produktív személy kibocsátását értékesebbnek tartja, a nagyobb időráfordítás miatt. Továbbá, ha a család minden tagja ugyanazt az ételt fogyasztja, ugyanazon étel elkészítése a család létszámától többé-kevésbé függetlenül csak

\footnotetext{
${ }^{6}$ Az NTA-ban a munkajövedelem nem csupán a bruttó béreket, de a munka teljes költségét, vagyis a munkáltató által fizetett járulékokat is magában foglalja. Ha azt szeretnénk, hogy az NTTA összhangban álljon az NTA-val, akkor ezeket a munkáltató által fizetett járulékokat is bele kell számitani a nem fizetett háztartási munkába. A munkáltatói hozzájárulások arányát a nemzeti számlák két tételének „munkavállalói jövedelmek összesen” és a „bérek és fizetések” arányaként becsültük meg (2010-ben 1,24).
} 
kicsivel több munkát igényel, és mindegy, hogy otthon vagy étteremben étkeznek. Ám az étterem output-árazást alkalmaz, így a számla összege igenis függ a család méretétől, míg az input megközelítés csupán csekély különbséget találna.

Az input megközelítés két fő hibája - a termelékenységkülönbségek és a méretgazdaságosság iránti érzéketlenség - miatt az idősek által végzett munka értékesebbnek tünik, mint amilyen valójában. Az előző bekezdésben ezt már bemutattuk a korspecifikus termelékenységkülönbségek esetében. A méretgazdaságosság is ilyen életkori hatást hoz létre, mert a háztartás mérete szintén korfüggő. Magyarországon az idősebb emberek jellemzően saját háztartásban, egyedül vagy párban, felnőtt gyermekeiktől külön élnek. Az ilyen háztartások mérete átlagosan kisebb, mint a kétgenerációs háztartásoké, amelyekben többnyire középkorú szülök és gyermekeik élnek. A korspecifikus termelékenységkülönbségek a minőségkorrekciós tényezőkhöz hasonló együtthatókkal kezelhetők, ám ez utóbbiak nem a tevékenység típusához, hanem az életkorhoz kapcsolódnak. Mindkét megoldás külső tudással egészíti ki az időmérlegvizsgálatot. Ezzel szemben a méretgazdaságosságot korrigáló tényezőket közvetlenül a felmérésből is nyerhetünk. A háztartás korspecifikus méretét közvetlenül a mintából is meg lehet becsülni, ezt pedig használhatjuk korrekciós tényezőként.

Az NTTA jelenlegi szabványa e két hiányosság egyikét sem korrigálja. Szerencsére az életkor-specifikus termelékenységkülönbség nincs hatással a cikkünkben tett megállapitásokra. Még ha túl is becsüljük az idősek által előállitott háztartási munka értékét, a fogyasztói is ők maguk, aminek a fent említett tipikus háztartási struktúra az oka, nevezetesen az, hogy az idősek kisebb, egygenerációs háztartásokban élnek. A nettó időtranszferek korprofilját tehát nem befolyásolja az, hogy a módszer érzéketlen a termelékenység különbségeire.

Az aktív korúak által megtermelt és a gyermekek által elfogyasztott háztartási munka értékének alulbecslését viszont nem tudjuk ily módon semlegesíteni. Mivel általában véve elhanyagoljuk a méretgazdaságosság hatását a háztartási munka értékére az életkori torzitástól függetlenül is, alulbecsüljük a nagyobb háztartásokban megtermelt és elfogyasztott értéket.

\section{A HÁZTARTÁSI MUNKA KORSZERKEZETE 2010-BEN}

A nemzeti transzferszámlák elkészitése során a kutatók erőfeszitései arra irányulnak, hogy megtalálják a már standardizált statisztikai eljárások során kialakított makroaggregátumok korprofiljait. Az NTTA-ban fordított a helyzet. A háztartási szatellitszámla makroaggregátumainak előállitása az időmérlegből 
még mindig messze nem általános, de ha egyszer adott, akkor az alapján már könnyen fel lehet rajzolni a korprofilokat. Az 1. ábrán bemutatjuk az egy före eső NTTA keresztmetszeti korprofiljait.

1. ábra: Hány havi átlagkeresetnek felel meg az egy före eső éves háztartási termelés, fogyasztás és nettó időtranszfer, 2010

Per capita annual household production, consumption and net time transfers in terms of average monthly labour cost, 2010

\section{Háztartási termelés}

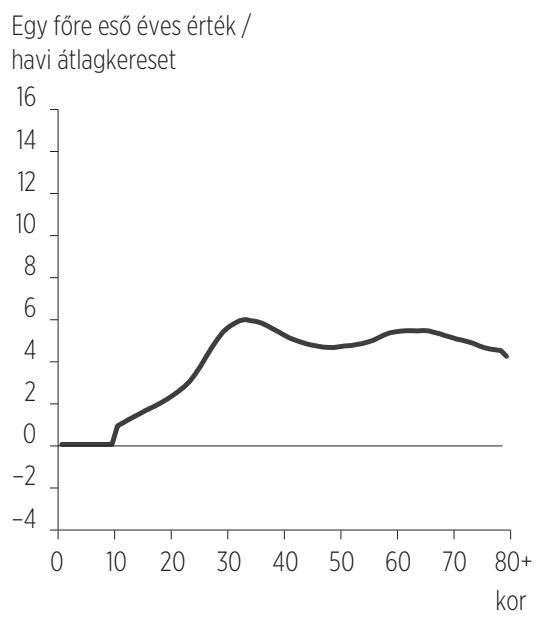

Háztartási szolgáltatások fogyasztása

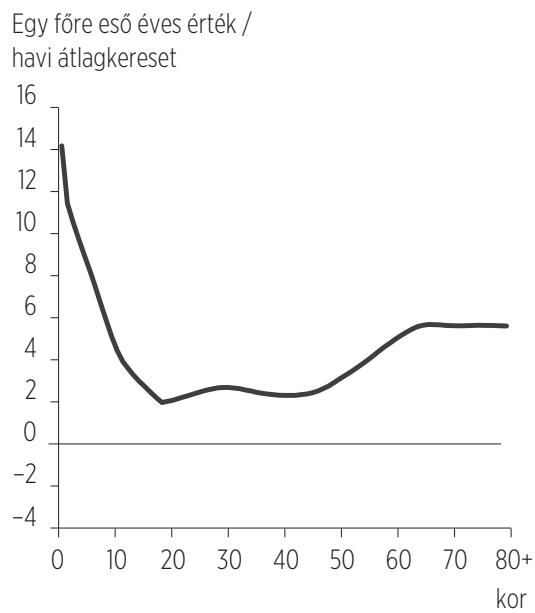

Nettó időtranszferek

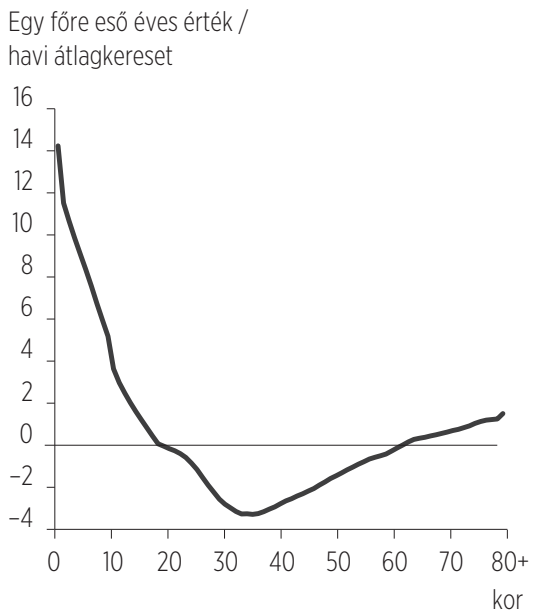

Forrás: A szerzők számítása a 2010. évi időmérleg-felvétel és bértarifa alapján.

Megjegyzés: Havi átlagkereset: az alkalmazásban állók havi bruttó átlagkeresete a „munkavállalói jövedelmek összesen” és a „bérek és fizetések” nemzeti számla tételek arányával korrigálva (2010-ben 251,672forint). 
A fizetett munkával szemben a háztartási munkát az emberek fiatalabban kezdik (lásd az 1. ábra baloldali paneljét). A „munkába állás” nem olyan éles határvonalú és a munkaterhelés viszonylag lassan nő az életkorral. A görbe a 30as korévek elején éri el az első csúcspontját, amikor az emberek sok időt szánnak kisgyermekeikre. E korosztályok körülbelül félévnyi keresetnek megfelelő értéket állítanak elő a háztartásban.?

Ahogy a gyermekek nőnek, önállóbbá válnak és végül kiköltöznek a háztartásból, az érintett évjáratok egy főre eső háztartási munkájának értéke csökken, s nem is növekszik addig, míg nyugdijjba nem mennek. Az OECD nyers részvételi és népességi adatai alapján készített számítás szerint 2010-ben a munkaerőpiac elhagyásának átlagos életkora valamivel 59 év alatt volt, minimális különbséggel a két nem között. ${ }^{8}$

A munkából való kilépés szintén különbözik a fizetett és a nem fizetett tevékenységek esetén. Magyarországon gyakorlatilag teljes lefedettséget biztosító felosztó-kirovó nyugdíjrendszer müködik, amely a fizetett munkából való tényleges nyugdijba vonulást néhány, 56 és 62 év közötti évjáratra korlátozza (2010-ben). Ezzel szemben a háztartási munka értéke épp a nyugdijjba vonulás után éri el második csúcspontját. Az emberek megnövekedett szabadidejük egy részét háztartási munkára fordítják. A görbe az idős korban végzett, kevésbé produktív munka értékét túlbecsülő, fenti torzító hatás jeleit is magán viselheti.

A piaci munkajövedelem a nyugdíjkorhatár felett gyakorlatilag teljesen eltűnik, de a háztartásban az emberek tulajdonképpen életük végéig dolgoznak. E tekintetben az 1. ábra baloldali paneljében bemutatott görbe inkább a vadászógyüjtögető társadalmakra jellemző korprofilokra hasonlít, semmint a fejlett országok munkajövedelmi görbéjére (lásd Lee és Mason 2011b).

\section{A HÁZTARTÁSI MUNKA FOGYASZTÁSA}

Egyes háztartási tevékenységek a háztartás egy adott tagjára irányulnak. Ilyen például a gyermekeknek a házifeladat-írásban nyújtott segítség. A KSH időmérleg-vizsgálat a fogyasztó személyét nem rögzíti, de a tevékenységi kódok jó, bár nem tökéletes indikátorként használhatók a háztartási javak és szolgáltatások

\footnotetext{
${ }^{7}$ Mivel a háztartási munka értékére vonatkozó becslésünk tartalmazza az imputált munkáltatói járulékot, kereseten e tanulmányban a 2010. évi havi átlagos teljes munkaköltséget értjük.

${ }^{8} \mathrm{~A}$ becslés az OECD népesség és munkaerőpiaci részvételi adatai alapján készült Latulippe-becsléssel (Latulippe, 1996).
} 
fogyasztójának megállapítására. Leginkább a gyermekgondozási tevékenységeket lehet korcsoport (például a 0-3, 4-6 és 7-14 év közöttiek) szerint könnyen hozzárendelni az adott kedvezményezetthez. Ha ugyanazon korosztályhoz egynél több gyermek is tartozik, a munka értékét egyenlően osztjuk meg közöttük. Az idősgondozás meghatározása nem ennyire egyértelmü. Az időmérleg-felvétel az idős vagy beteg személy gondozására ugyanazokat a kódokat használja. Mivel nem tudjuk, ki beteg az adott háztartásban, ezeket az értéket az idősekhez rendeljük (60 éves vagy ennél idősebb) abban az esetben, ha vannak idősek a háztartásban; ha viszont nincsenek, akkor a háztartás tagjai egyenlően részesednek belőle.

Más tevékenységek az egész háztartás javát szolgálják. A kitakarított lakás vagy az elkészített étel előnyeit a háztartás minden tagja élvezi. Ahhoz, hogy az ilyen eseteket is kezelni tudjuk, olyan algoritmusra van szükségünk, amely a munka értékét szétosztja közöttük. Az NTTA standard a teljes ekvivalencia feltevését használja, vagyis a háztartási közszolgáltatásokat egyenlően osztja szét a háztartástagok között.

A háztartáson kívülre adott időtranszferek speciális eljárást igényelnek, mivel az időmérleg-vizsgálat csak a munkavégzést rögzíti, de nem jegyzi fel a háztartáson kívüliek javára végzett munka kedvezményezettjeit. Efféle időtranszfert kétféleképpen lehet nyújtani: ha a vizsgált személy a háztartáson kívül végez nem fizetett munkát, vagy ha a munkát ugyan a háztartáson belül végzik, de fogyasztója nem háztartástag. Ezeket a tevékenységeket (az időmérleg szerint az összes háztartási tevékenység 4,6\%-a) a háztartáson belüli fogyasztás koreloszlása alapján osztjuk szét a teljes népességben.

Az 1. ábrán a jobboldali panelben tüntetjük fel a nem fizetett háztartási munka fogyasztóinak korprofilját. Látható, hogy a fogyasztás aktív korban viszonylag alacsony, időskorban viszont több mint kétszer akkora, kisgyermekek esetében pedig még több. Úgy tűnik, hogy a háztartási munka vagy háztartási közjavakat állít elő, amelyeket a háztartás valamennyi tagja egyaránt fogyaszt, vagy gyermekeknek és kisebb mértékben időseknek szánt javakat és szolgáltatásokat hoz létre.

\section{IDŐTRANSZFEREK}

Az 1. ábra harmadik, alsó paneljén tüntetjük fel a fogyasztott és az elvégzett munka különbségét korévenként. Mint a korábbiakban már jeleztük, a nemzetközi konvenciót követve (nettó) időtranszfernek nevezzük e különbségeket. Az ábra világosan mutatja, hogy a háztartásgazdaságban - legalábbis Magyar- 
országon - egyirányú áramlás zajlik a szülőktől a gyermekekhez. A nettó időtranszfer a kisgyermekek esetében kiugróan magas, közülük is a legfiatalabbak kapják a legtöbb időtranszfert, ez aztán a korral csökken. Egy újszülött az első életévben átlagosan a havi kereset 14-szeresének megfelelő erőforrást kap időtranszferként; egy hétéves a 7-szeresét, míg egy 14 éves a háromszorosát. 18 és 62 éves kor között negatív a nettó időtranszfer értéke. Ezek a korosztályok ugyanis a háztartásgazdaság nettó finanszírozói; az ő háztartási termelésük értéke magasan meghaladja azt, amit ebből maguk fogyasztanak. A 63 évesek és a náluk idősebbek ismét, bár csak kismértékben a háztartási szolgáltatások nettó kedvezményezettjei.

\section{FÉRFIAK, NŐK ÉS AZ IDÖTRANSZFEREK}

A 2. ábra nemi bontásban mutatja az egyes korévekre jellemző termelés, fogyasztás és a nettó időtranszferek átlagos egy főre eső értékeit. A baloldali panel jól illusztrálja, hogy a nők összességében többet dolgoznak a háztartásban, mint a férfiak; de a koréves bontás alapján az is kiderül, hogy a férfiak és a nők közötti különbség eltér a különböző korévekben. A legnagyobb különbség átlagosan a húszas évek végén és a harmincas években levő nők és férfiak között van, amikor a nők a legnagyobb eséllyel vannak otthon kisgyermekeikkel. A férfiak és nők közötti termelés különbsége a korral lecsökken, és sokkal kisebb mértékben, de újra megnő a 60-as korévek elején. A nőkre inkább jellemző egy kétmóduszú korprofil, mint a férfiakra. A jobboldali panelről leolvasható, hogy a háztartási javak és szolgáltatások fogyasztása nem tér el számottevően a férfiak és a nők között.

A 2. ábra harmadik, alsó panelje a nettó időtranszfereket mutatja nemi bontásban. A panelről egyértelműen kiderül, hogy az, amit a fentiekben általában az aktív korúaknak tulajdonítottunk, valójában szinte kizárólag a nőknek köszönhető. Elsősorban az aktív korú nők a háztartásgazdaság nettó finanszírozói. Míg a nők átlagosan majdnem egész életük során, 17 éves kortól 73 éves korig adnak nettó időtranszfereket, addig a férfiakra átlagosan ez csak 30 és 53 éves kor között jellemző. Az 54 éves vagy idősebb férfiak 2010-ben átlagosan 1,3 havi keresetnek megfelelő időtranszfert kaptak. Ez az érték azonban eltörpül a 0-17 éves gyermekek által átlagosan kapott nettó háztartási javak és szolgáltatások mértékétől, amelynek értéke 5,6 havi keresettel ért fel 2010-ben. 
2. ábra: Hány havi átlagkeresetnek felel meg az egy före eső éves háztartási termelés, fogyasztás és nettó időtranszfer nemenként, 2010

Figure 2: Per capita annual household production, consumption and net time transfers by gender in terms of average monthly labour cost, 2010

\section{Háztartási termelés}

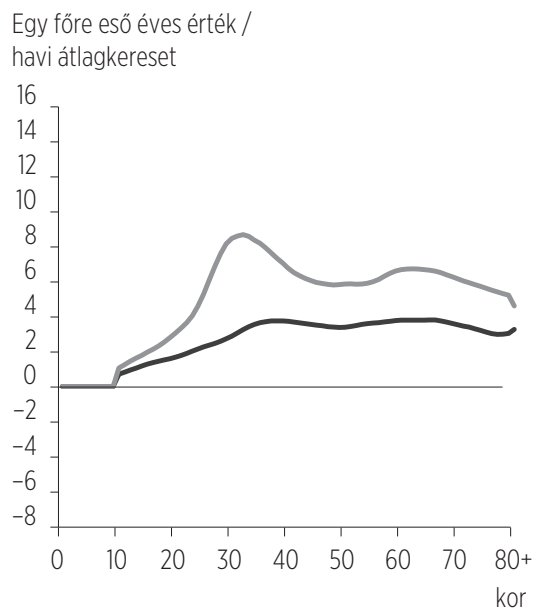

Háztartási szolgáltatások fogyasztása

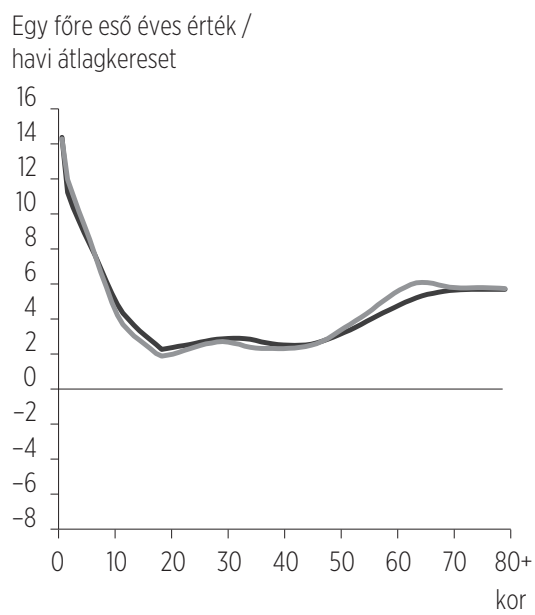

Nettó időtranszferek

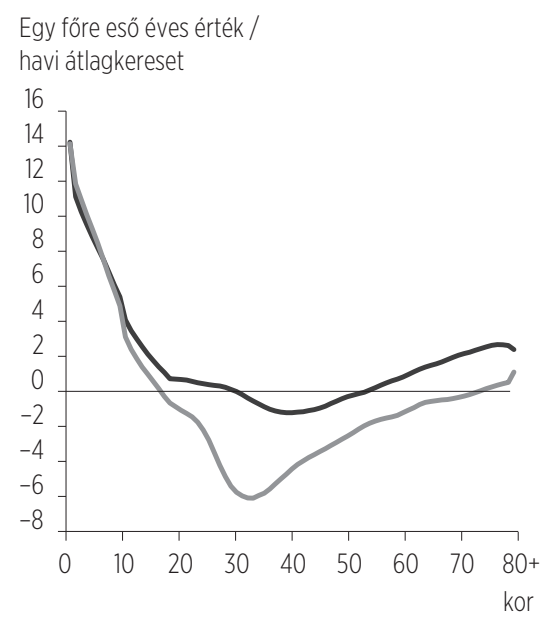

一 Férfiak Nők

Forrás: A szerzők számítása a 2010. évi időmérleg-felvétel és bértarifa alapján.

Megjegyzés: Havi átlagkereset: az alkalmazásban állók havi bruttó átlagkeresete a „munkavállalói jövedelmek összesen” és a „bérek és fizetések” nemzeti számla tételek arányával korrigálva (2010-ben 251,672 forint). 


\section{ÖSSZEFOGLALÁS}

A 2009/2010-es időmérleg adatai alapján először megvizsgáltuk a háztartásban végzett nem fizetett munka koreloszlását nemek szerint. A következő lépésben részben az időmérleg adatokból közvetlenül nyerhető információ alapján, részben pedig egy elosztási szabály szerint megkerestük az e munka révén elóállított javak és szolgáltatások fogyasztóit és felrajzoltuk a nemek szerinti fogyasztási korprofilokat is. A feladatok elvégzése során a nemzeti időtranszfer számlák módszertanának nemzetközi standardjait használtuk. Az életkor dimenziójának bevonásával bemutattuk, hogy a háztartásgazdaság nem csak nemek között, hanem életkorok között mozgat transzfereket. 


\section{IRODALOM}

Donehower, Gretchen 2011: Incorporating gender and time use into NTA: National Time Transfer Accounts methodology. University of California, Dept. of Demography, Berkeley. Kézirat.

European Communities 2003: Household production and consumption: Proposal for a methodology of household satellite accounts. Office for Official Publications of the European Communities, Luxembourg.

Gál, Róbert Iván - Szabó, Endre - Vargha, Lili 2015: The age-profile of invisible transfers: the true size of asymmetry in inter-age reallocations. Journal of the Economics of Ageing, 5, 98-104.

Gál Róbert Iván - Vargha Lili 2015: Generációk közötti erőforrás-átcsoportosítás. In Monostori Judit - Őri Péter - Spéder Zsolt (szerk.): Demográfiai portré, 2015. KSH Népességtudományi Kutatóintézet, Budapest, 135-150.

Gál, Róbert Iván - Vanhuysse, Pieter - Vargha, Lili 2018: Pro-Elderly Welfare States within Child-Oriented Societies. Journal of European Public Policy, 25(6), 944-958.

Latulippe, Dennis 1996: Effective retirement age and the duration of retirement in the industrial countries between 1950 and 1990. ILO Issues in Social Protection Discussion Papers 2. ILO, Geneva.

Lee, Ronald D. 1994a: The formal demography of population aging, transfers, and the economic life cycle. In Martin, Linda G. - Preston, Samuel H. (szerk.): The demography of aging. National Academy Press, Washington DC, 8-49.

Lee, Ronald D. 1994b: Population age structure, intergenerational transfers, and wealth: a new approach, with applications to the US. Journal of Human Resources, special issue edited by Paul Gertler, The Family and Intergenerational Relations, 29(4), 1027-63.

Lee, Ronald D. - Mason, Andrew (szerk.) 2011a: Population Aging and the Generational Economy: A Global Perspective. Edward Elgar, Cheltenham UK and Northampton MA.

Lee, Ronald D. - Mason, Andrew 2011b: Lifecycles, support systems, and generational flows: patterns and change. In Lee, Ronald D. - Mason, Andrew (szerk.): Population Aging and the Generational Economy: A Global Perspective. Edward Elgar, Cheltenham UK and Northampton MA, 79-106.

Sik Endre - Szép Katalin (szerk.) 2003. A háztartasi termelés érteke a mai Magyarországon. A háztartási szatellitszámla 2000. évi kisérleti számitásai. KSH, Budapest.

Szép Katalin - Szőkéné Boros Zsuzsanna (szerk.) 2017: A háztartási termelés értéke Magyarországon. KSH, Budapest.

United Nations 2013: National Transfer Accounts Manual: Measuring and analysing the generational economy. New York NY: United Nations.

Vargha, Lili - Gál, Róbert Iván - Crosby-Nagy, Michelle 2017: Household production and consumption over the lifecycle: National Time Transfer Accounts in 14 European countries. Demographic Research, 36(32), 905-944. 


\section{INVISIBLE TRANSFERS: WHO ARE THE PRODUCERS OF UNPAID HOUSEHOLD LABOUR AND WHO CONSUMES THEIR PRODUCT?}

Based on the 2009/2010 Hungarian Time Use Survey the autors analyse the distribution of household production as well as the consumption of its products and services by age and gender. To put it simply they give a primary demographic portrayal of the so-called household satellite account, which describes the household economy. The results confirm the well-documented division of labour between genders, however adding the age dimension the authors specify this division further. The female age profile is more pronouncedly bimodal than the male profile. The difference between the genders is present in every age group above age 10; it is the largest at the age of having little children. The authors show that intrafamilial time transfers flow not only among genders, but among age groups as well. Hungarian men between the age of 30 and 53 are net providers of time transfers. An average 54-year-old or older man receives time transfers equivalent to 1.3 months of wages. In contrast, an average child between the age of 0 and 17 gets a value of 5.6 months of wages. 